Binghamton University

The Open Repository @ Binghamton (The ORB)

Fall 2013

\title{
Public Administration Education in Latin America-Understanding Teaching in Context: An Introduction to the Symposium
}

\author{
Nadia Rubaii \\ Binghamton University--SUNY, nadia.rubaii@binghamton.edu \\ Cristian Pliscoff \\ University of Chile
}

Follow this and additional works at: https://orb.binghamton.edu/public_admin_fac

Part of the Public Administration Commons

\section{Recommended Citation}

Rubaii, N. M., \& Pliscoff, C. (2013). Public Administration Education in Latin America-Understanding Teaching in Context: An Introduction to the Symposium. Journal of Public Affairs Education,19(4). 585-589.

This Article is brought to you for free and open access by the Public Administration at The Open Repository @ Binghamton (The ORB). It has been accepted for inclusion in Public Administration Faculty Scholarship by an authorized administrator of The Open Repository @ Binghamton (The ORB). For more information, please contact ORB@binghamton.edu. 


\title{
Public Administration Education in Latin America-Understanding Teaching in Context: An Introduction to the Symposium
}

\author{
Nadia M Rubaii \\ Binghamton University \\ Cristian Pliscoff \\ University of Chile
}

In public administration and public policy, context matters. Although many of the core functions of public administrators and terms used to refer to fundamental public service values are similar throughout the world, the meaning and application of knowledge, skills, and abilities can vary greatly depending on the context in which public administrators work. Public affairs education must be responsive to these differences. If the practice of public administration is uniquely affected by place with all of its corresponding political, cultural, and economic systems and norms, so too must the education of public administrators. So what is the Latin American context, and to what extent and in what ways does it shape public affairs education? That is the focus of this symposium.

Current and future public administrators in Latin America are faced with many of the same challenges confronting public officials elsewhere in terms of enhancing economic development; promoting improved health, education, and security; and reducing crime, inequality, discrimination, and poverty. But they must do so in a region with generally weak public finances, various manifestations of corruption, and lack of social recognition for professional public administration due to a history of malfunctioning government and poorly conceived and implemented reforms. In this context, understanding how public affairs education is structured and implemented in the region is crucial to understanding the practice of public administration in Latin America.

Latin America is a region of sharp contrasts. It has well-developed areas with affluent populations where incomes are as high as any of the Organisation for Economic Co-operation and Development (OECD) countries, and other areas where large populations live in abject poverty. Countries in the region employ a 
variety of political, governmental, and educational models (Pulido, Cravioto, Pereda, Rondo, \& Pereira, 2006) to serve their populations who speak not only Spanish, Portuguese, French, English, and Dutch but also hundreds of indigenous languages. In some Latin American countries, public agencies are leading the use of new technologies or have developed new techniques to improve efficiency and effectiveness in service delivery, whereas others are riddled with maladministration and corruption. Higher education systems in Latin America differ dramatically in terms of size, the relative proportion of public and private institutions, and the level of accessibility (Garcia Guadilla, 2000; Holm-Nielsen, Thorn, Brunner, \& Balán, 2005). They also differ in terms of the existence and prominence of professional graduate degree programs designed to prepare public administrators.

An underlying assumption of professional graduate degree programs in public administration and public policy is that professional public affairs education can improve the quality of government and governance. Nations with quality higher education systems generally rate higher on public commitment to civic virtue and experience lower rates of corruption (Arruda Filho, 2012). Throughout the region, there is a consensus about the need for government officials to demonstrate higher levels of professionalism. In an increasingly interdependent global world, the complex or "wicked problems" of governance—poverty, malnutrition, illiteracy, discrimination, environmental degradation, human rights abuses, violence, crime, rampant corruption, and the like-demand professional public administrators at all levels of government. Professionalism, in this context, implies not only competence in the form of knowledge and skills but also a high standard of ethics and a commitment to the values of democracy, transparency, participation, and accountability. MPA programs "are a key resource in advancing sustainable human, economic and administrative development by providing graduates with knowledge and technical skills, along with an awareness of justice and equity in the public service" (Newman \& Rubin, 2009, p. 2).

To be effective in this role, public administration programs must prepare graduates with a full range of competencies, including knowledge, skills, and public service values, and they must do so in ways that are relevant to the culture and context where public administrators will work. Program design, course content, and the roles and relations among academic, government, and civil society organizations in the provision of public affairs education need to be tailored to historical and current political and policy environment. Unfortunately, this is not the case in Latin America, because most of the literature, cases, methodologies, and theories were drawn initially from Europe and in later years from the United States.

There are plenty of scholarly works on the political and administrative functions (or dysfunctions) within individual countries in Latin America and across the region. Particularly relevant is the work of the Centro Latinoamericano de Administración para el Desarrollo, or CLAD [Latin American Center for Development Administration], which hosts an annual conference, where practitioners and scholars share ideas regarding the state of the art in this area. CLAD also publishes 
a journal, Reforma y Democracia [Reform and Democracy], that is one of the few journals in our field included in the Thompson Reuters ISI Journal Citation Index. Similarly, the journal Gestión y Politica Pública [Management and Public Policy], edited by the Centro de Investigación y Docencia Económicas, or CIDE [Center for Research and Teaching in Economics] in Mexico, also provides an outlet to disseminate academic work in public administration and public policy. The efforts in these venues are largely scientific and practitioner oriented; what is lacking is a focus on public affairs education in these contexts.

The three papers in this symposium contribute greatly to the foundation knowledge on the status of public affairs education in Latin America and the extent to which, and manner in which, public affairs education is responsive to context. Individually they provide country case studies of particular aspects of public affairs education in Ecuador, Mexico, and Brazil. In its own way, each article provides insights into the historical and present-day factors that result in current demands being met or not being met by existing public affairs programs. Collectively, they provide the basis for appreciating the diversity and challenge across the region.

In the first article, Susan Appe and Daniel Barragán begin by noting the absence of formal nonprofit management education within universities in Ecuador and then share insights into how nonprofit organizations in Ecuador are filling this gap by producing and disseminating knowledge about nonprofit management. Using participatory research and content analysis of archival documents, Appe and Barragán illustrate that this approach, while outside the formal university structure, still promotes the values of transparency, ethics, and accountability and the corresponding skills of managing a nonprofit to reflect those values. Nonprofit organizations in Ecuador are thus crucial players in this aspect of public affairs education, and the systems they have developed are critical to organizational success.

The values of transparency, ethics (anticorruption), and accountability (public service and good governance) are also vital in the Mexican context, according to the article by Abraham Benavides, Adira Fierro-Villa, and Eduardo Cobian Aguayo. They make the case that the explicit attention to public service, justice, transparency, and good governance- as core values and as content within public administration courses - are essential to combat the tradition of corruption and the current problem of drug-related violence in Mexico. They then examine MPA programs throughout the country to determine the extent to which the curriculum reflects attention to these values and to the skills needed to practice such values. They identify differences in scope of coverage across the four values and across regions of Mexico. In so doing, they help the reader appreciate in what areas, substantive and geographic, additional attention is needed.

The Brazilian case study presented in the final article by Fátima Bayma Oliveira and Marilyn Marks Rubin is not limited to a specific subfield of public affairs education or the content of program courses. Instead, they provide a detailed history of the development of public affairs education at all levels within Brazil. In this way, the reader is provided with a greater appreciation for the historical 
and political factors affecting public affairs education in Brazil and its place within the nation's broader system of higher education. Oliveira and Rubin identify challenges and opportunities associated with the current institutional arrangements and make specific recommendations for how to improve the structure and operation of public administration education in the Brazilian context.

We are particularly pleased that each article in the symposium represents an international partnership and coproduction of knowledge with teams from the United States and the three Latin American countries studied. In this way, these articles do not simply represent an outsider's assessment but also benefit from a within-country lens. We also note that the authors include scholars who are well established as well as those just starting their academic careers, and universitybased faculty and researchers as well as public administration practitioners. We are confident that the coauthors of each article have found the process of working together across geographic and cultural differences to be as rewarding and informative as the process has been for the two of us as guest editors. As NASPAA embraces its role as the global standard in public service education and expands the scope of its international activities, we hope that this symposium represents only the first step in a process of internationalization of topics and authors on the pages of JPAE.

Saludos a todos y esperamos que los siguientes artículos sean de su interés, así como también que puedan aprender de la difusión de experiencias desarrolladas en América Latina expresados en los tres artículos de este simposio. [Best wishes to all, and we hope that the following articles are of interest, and that you are able to learn from the dissemination of unfolding experiences in Latin America expressed in the three articles in this symposium.]

\section{REFERENCES}

Arruda Filho, N. (2012, July 16-21). Perspectivaction educational model. Paper presented at the 2012 IASIA Annual Conference, Bangkok, Thailand.

Garcia Guadilla, C. (2000). The institutional basis of higher education research in Latin America with special emphasis on the role played by international and regional organizations. In S. Schwartz \& U. Teichler (Eds.), The institutional basis of higher education research (pp. 117-135). Dordrecht, The Netherlands: Kluwer Academic Publishers.

Holm-Nielsen, L. B., Thorn, K., Brunner, J. J., \& Balán, J. (2005). Regional and international challenges to higher education in Latin America. In H. De Witt, C. Jaramillo, J. Gacel-Avila, \& J. Knight (Eds.), Higher education in Latin America: The international dimension (pp. 39-69). Washington, DC: World Bank Publications.

Newman, M. A., \& Rubin, M. (2009, November). Towards excellence in public sector performance: The MPA approach. Paper presented at the Institute of Public Administration's International Conference on Administrative Development, Riyadh, Saudi Arabia.

Pulido, P. A., Cravioto, A., Pereda, A., Rondo, R. N., \& Pereira, G. (2006). Changes, trends, and challenges of medical education in Latin America. Medical Teacher, 28(1), 24-29. 
Nadia Rubaii is associate professor of Public Administration in the College of Community and Public Affairs at Binghamton University, State University of New York. Her research interests focus on diversity, broadly defined, including pedagogies to develop cultural competence, human resource management practices to promote diversity, and municipal policies to integrate immigrant populations. She served as president of NASPAA in 2011-12 and currently serves on both the Executive Board and the Accreditation Committee of the InterAmerican Network for Public Administration Education (INPAE). In 2014 she will be a Fulbright Scholar in Colombia at Pontificia Universidad Javeriana, where she will be studying the challenges of international accreditation of public affairs programs in Latin America.

Cristian Pliscoff is director of the School of Government and Public Management in the Institute of Public Affairs at the University of Chile in Santiago. He holds a PhD in Public Administration from the University of Southern California. $\mathrm{He}$ is assistant professor, and his research interests are in public sector reform, public service motivation, public values in Latin America, and pedagogy and teaching techniques in public administration education. He is a member of the Executive Board of INPAE. 